\title{
Pojęcie pracownika w świetle przepisów Kodeksu pracy i ustawy o systemie ubezpieczeń społecznych
}

\author{
1. Wstęp
}

Jak wiemy prawo pracy pozostaje w różnych relacjach, z różnym stopniem nasilenia, do wielu gałęzi prawa. Na potrzeby niniejszego opracowania chciałabym ukazać różnice jakie występują w samej definicji pracownika ujętej w ustawie o systemie ubezpieczeń społecznych ${ }^{2}$ z 13.10 .1998 r. oraz w ustawie - Kodeks pracy ${ }^{3}$ z 26.06.1974 r.

\section{Pojęcie pracownika w Kodeksie pracy}

Zgodnie z art. 2 Kodeksu pracy, pracownikiem jest osoba zatrudniona na podstawie umowy o pracę, powołania, mianowania lub spółdzielczej umowy o pracę. Artykuł stanowi formalną definicję pojęcia pracownika. Wyliczenie w art. 2 k.p. aktów, które kreują stosunek pracy ma charakter enumeratywny. Tym samym nie może być rozszerzone na inne podstawy ${ }^{4}$. Tego rodzaju opcja interpretacyjna wynika $z$ imperatywnego charakteru art. 2 Kodeksu pracy. W praktyce oznacza to, że podmioty funkcjonujące w stosunkach pracy nie są uprawnione do tworzenia samoistnych podstaw stosunku pracy, choćby w ramach nienazwanych umów prawa pracy ${ }^{5}$. Podmioty, które funkcjonują w stosunkach pracy muszą poruszać się w granicach zakreślonych w art. 2 k.p., nie obowiązuje ich swoboda umów ${ }^{5}$. Taksatywność wyliczenia aktów kreujących stosunek pracy w komentowanym przepisie nie oznacza numerus clausus w wymiarze kontraktowym. De lege lata umowy o pracę są regulowane zarówno w przepisach kodeksowych np. art. 25 i 194 Kodeksu pracy, jak i pozakodeksowych. Klasycznym przykładem pozakodeksowej umowy o specyficznej trójstronnej strukturze jest umowa o pracę tymczasową, regulowana odrębną ustawą ${ }^{5}$.

Definicja pracownika wynika również z art. 22 ust. 2 Kodeksu pracy, który stanowi, że pracownikiem może być osoba, która ukończyła 18 lat. Na warunkach określonych w dziale dziewiątym Kodeksu pracy, pracownikiem może być również osoba, która nie ukończyła 18 lat. Z powyższego artykułu należy

\footnotetext{
${ }^{1}$ Doktorant, Uniwersytet Łódzki, Wydział Prawa i Administracji, Katedra Prawa Pracy.

${ }^{2}$ Ustawa z 13.10.1998 r. o systemie ubezpieczeń społecznych, Dz.U. z 1998 r. Nr 137, poz. 887 ze zm.

${ }^{3}$ Ustawa z 26.06.1974 r. - Kodeks pracy, Dz.U. z 1998 r. Nr 21, poz. 94 ze. zm.

${ }^{4}$ K. W. Baran (red.), Kodeks pracy. Komentarz, 2014, s. 24.

${ }^{5}$ Ibidem, s. 24.
} 
przyjąć, że pracownikiem może być wyłącznie osoba fizyczna. Użycie wyrazu „osoba” w treści tego artykułu stanowi, że termin „pracownik” nie może się odnosić do osoby prawnej ${ }^{6}$. Wniosek taki wynika m. in. z analizy innych przepisów, chociażby z art. $63^{1} \S 1$ Kodeksu pracy, który stanowi, iż z dniem śmierci pracownika stosunek pracy wygasa ${ }^{7}$, jak również ze sprzeczności niektórych cech stosunku pracy z naturą osób prawnych, np. osobiste wykonanie pracy czy też minimalny wiek zatrudnionego ${ }^{8}$.

- Pracownikami według Kodeksu pracy nie są w szczególności osoby:

- zobowiązujące się do wykonania jakiegoś dzieła na podstawie umowy o dzieło (art. 627 i n. ustawy Kodeks cywilny) ${ }^{9}$,

- dokonujące określonej czynności prawnej na podstawie umowy zlecenia (art. 734 i n. oraz art. 750 ustawy Kodeks cywilny),

- tzw. agenci, czyli osoby przyjmujące zlecenie na podstawie umowy agencyjnej, które zobowiązują się za wynagrodzeniem do stałego pośredniczenia przy zawieraniu z klientami umów na rzecz dającego zlecenie przedsiębiorcy albo zawierania ich w jego imieniu (art. 758 i n. ustawy Kodeks cywilny).

Prawa i obowiązki wymienionych wyżej osób określa nie prawo pracy, a prawo cywilne. Osoby te wykonują pracę na podstawie tzw. umów cywilnoprawnych.

Pracownikami w rozumieniu Kodeksu Pracy nie są również:

1) osoby prowadzące jednoosobową działalność gospodarczą. Działalnością gospodarczą w rozumieniu ustawy o swobodzie działalności gospodarczej ${ }^{10}$ jest zarobkowa działalność wytwórcza, budowlana, handlowa, usługowa oraz poszukiwanie, rozpoznawanie i wydobywanie kopalin ze złóż, a także działalność zawodowa, wykonywana w sposób zorganizowany i ciągły. We wspomnianej ustawie osoba taka została określona jako przedsiębiorca. Zgodnie $\mathrm{z}$ art. 4 ust. 1 przedsiębiorcą jest osoba fizyczna, osoba prawna i jednostka organizacyjna nie będąca osobą prawną, która prowadzi działalność gospodarczą we własnym imieniu i na własne ryzyko;

2) zatrudnieni w tzw. służbach mundurowych: policjanci, funkcjonariusze Agencji Bezpieczeństwa Wewnętrznego, Straży Granicznej, zawodowi żołnierze oraz funkcjonariusze Państwowej Straży Pożarnej. W tych przypadkach mamy do czynienia ze stosunkiem administracyjnym, który regulowany jest przez tzw. pragmatyki służbowe. Liczba aktów zaliczanych do pragmatyk administracyjnych jest obszerna, a same akty mają zróżnicowany charakter. W tym przypadku przepisy powszechnego prawa pracy znajdują za-

\footnotetext{
${ }^{6}$ L. Florek (red.), Kodeks pracy. Seria Komentarzy, Lex 2011.

${ }^{7}$ P. Korus, [w:] A. Sobczyk (red.), Kodeks pracy. Komentarz, Legalis 2015.

${ }^{8}$ Ibidem.

${ }^{9}$ Ustawa z 23.04.1964 r. Kodeks cywilny, Dz.U. z 1964 r. Nr 16, poz. 93 ze zm.

${ }^{10}$ Ustawa z 02.07.2004 r. o swobodzie działalności gospodarczej, Dz.U. z 2004 r. Nr 173, poz. $1807 \mathrm{ze} \mathrm{zm}$.
} 
stosowanie wyłącznie w sytuacji wyraźnego odesłania zawartego w takiej pragmatyce bądź w sytuacji braku odpowiedniej regulacji w pragmatyce;

3) osoby wykonujące pracę nakładczą, zwane chałupnikami. Korzystają tylko z niektórych uprawnień pracowniczych na zasadzie odesłania do Kodeksu pracy w rozporządzeniu Rady Ministrów z 31.12.1975 r. w sprawie uprawnień pracowniczych osób wykonujących pracę nakładczą ${ }^{11}$;

4) członkowie innych spółdzielni niż spółdzielnie pracy, np. członkowie rolniczych spółdzielni produkcyjnych ${ }^{12}$. Członkowie rolniczych spółdzielni produkcyjnych pozostają z tymi spółdzielniami w niepracowniczych stosunkach prawnych, które regulowane są przez prawo spółdzielcze;

5) senatorowie, posłowie. Mamy tutaj do czynienia z zatrudnieniem typu konstytucyjnego, ustrojowego. Posłowie i senatorowie działają na podstawie ustawy z dnia 9 maja 1996 r. o wykonywaniu mandatu posła i senatora ${ }^{13}$. Stosunek pracy posła jest objęty szczególną ochroną prawną, która polega na tym, że nie można go zasadniczo rozwiązać w czasie trwania kadencji i w 2 lata po jej zakończeniu. Poseł, na czas kadencji, przebywa na urlopie bezpłatnym, który pracodawca jest zobowiązany udzielić na jego wniosek. W przypadku gdy, poseł nie korzysta z urlopu bezpłatnego, pracodawca zobowiązany się bezwzględnie umożliwić posłowi wykonywania obowiązków parlamentarnych na zasadzie pierwszeństwa nad pracowniczymi;

6) osoby skazane. Zgodnie z art. 121 ust. 2 Kodeksu karnego wykonawczego $^{14}$ osoby zatrudnione na podstawie skierowania przez organy więzienne do pracy, działają na podstawie prawomocnego wyroku skazującego, a nie na podstawie umowy dwóch równorzędnych podmiotów, jakimi są pracownik i zakład pracy ${ }^{15}$. Art. 121 ust. 9 Kodeksu karnego wykonawczego stanowi, że w stosunku do skazanych zatrudnionych na podstawie skierowania do pracy nie stosuje się przepisów prawa pracy, z wyjątkiem przepisów dotyczących czasu pracy oraz bezpieczeństwa i higieny pracy ${ }^{16}$. W doktrynie zatrudnienie powyższe nosi miano zatrudnienia penalnego.

Jak widać nie każdy człowiek ,pracujący” w znaczeniu ogólnym, potocznym tego słowa, który wykonuje jakąś działalność zwaną pracą, fizyczną czy też umysłową, jest pracownikiem w znaczeniu prawnym, według Kodeksu pracy ${ }^{17}$.

\footnotetext{
${ }^{11}$ Rozporządzenie Rady Ministrów z 31.12.1975 r. w sprawie uprawnień pracowniczych osób wykonujących pracę nakładczą, Dz.U. z 1976 r. Nr 3, poz. 19 ze zm.

${ }^{12}$ P. Korus, op. cit.

${ }^{13}$ Ustawa z 09.05.1996 r. o wykonywaniu mandatu posła i senatora, Dz.U. z 2011 r. Nr 7, poz. 29 ze zm.

${ }^{14}$ Ustawa z 06.06.1997 r. - Kodeks karny wykonawczy, Dz.U. z 1997 r. Nr 90, poz. 557, ze zm.

${ }^{15} \mathrm{O}$. Stanowska, Zatrudnienie skazanych pozbawionych wolności na podstawie skierowania do pracy, „RPiA”2014, s. 213.

${ }^{16}$ Ibidem, s. 215.

${ }^{17}$ L. Florek (red.), Kodeks pracy. Seria Komentarzy, Lex 2011.
} 
Zgodnie z art. 2 Kodeksu pracy, pracownik to osoba, która zatrudniona jest na podstawie umowy o pracę, powołania, wyboru, mianowania lub spółdzielczej umowy o pracę. Ten sposób określenia pracownika nie może być przeniesiony wprost na grunt stosunków ubezpieczenia społecznego, gdyż nie w pełni odpowiada pojęciu, którym posługują się art. 6 ust. 1 pkt. 1 i art. 8 ust. 1 ustawy o systemie ubezpieczeń społecznych ${ }^{18}$. W szczególności, pojęcie pracownika w rozumieniu ustawy systemowej jest szersze od pojęcia zdefiniowanego w prawie pracy, gdyż na potrzeby ubezpieczenia za pracownika uważa się także niektóre osoby, wykonujące zatrudnienie poza stosunkiem pracy (art. 8 ust. 2a), a jednocześnie spod pojęcia pracownika wyłącza się osoby, które pozostają w stosunku pracy, prokuratorów, sędziów oraz osoby spełniające kryteria określone dla osób współpracujących (art. 8 ust. 2, ust. 11 i 15 ustawy) ${ }^{19}$.

\section{Pojęcie pracownika w ustawie o systemie ubezpieczeń społecznych}

Ubezpieczenie społeczne pracowników stanowi trzon i pierwotną podstawę wszystkich późniejszych systemów ubezpieczenia, których rozwój polegał m.in. na rozszerzaniu ochrony na inne podmioty, czerpiące środki utrzymania z własnej aktywności zawodowej ${ }^{20}$.

Art. 6 ust. 1 pkt. 1 stanowi, iż pomimo posiadania statusu pracownika, nie podlegają obowiązkowi ubezpieczenia społecznego prokuratorzy i sędziowie, jakkolwiek tych ostatnich nie wymienia nawet jako grupy wyłączonej z obowiązku ubezpieczenia społecznego. Należy się zgodzić z Inettą Jędrasik-Jankowską, że jest to niewątpliwie błąd natury legislacyjnej, którego przyczynę trudno zgadnąć ${ }^{21}$. Sędziowie bowiem, podobnie jak prokuratorzy, objęci są nie systemem ubezpieczenia społecznego, lecz zaopatrzenia społecznego, które realizowane jest $\mathrm{z}$ budżetu państwa ${ }^{22}$. Dokonało się to w stosunku do sędziów ustawą z 28 sierpnia 1997 r. o zmianie ustawy - Prawo o ustroju sądów powszechnych oraz niektórych innych ustaw ${ }^{23}$, natomiast $\mathrm{w}$ stosunku do prokuratorów, odpowiednia zmiana ustawy z 20 czerwca 1985 r. o prokuraturze ${ }^{24}$, dokonana została ustawą z 17 grudnia 1997 r., o zmianie ustawy - Prawo ustroju sądów powszechnych oraz niektórych innych ustaw. Wyłączenie sędziów z systemu

\footnotetext{
${ }^{18}$ B. Gudowska, [w:] B. Gudowska, J. Strusińska-Żukowska (red.), Ustawa o systemie ubezpieczeń społecznych. Komentarz, Warszawa 2011, s. 171-172.

${ }^{19}$ Ibidem, s. 171-172.

${ }^{20}$ Ibidem, s. 81-82.

${ }^{21}$ I. Jędrasik-Jankowska, Ubezpieczenie społeczne, Tom 1, Część ogólna, Warszawa 2003, s. 89.

${ }^{22}$ G. Wolak, Podleganie przez sędziów ubezpieczeniu społecznemu z tytułu zawarcia umowy zlecenia, „PiZS” 7/2014, s. 26.

${ }^{23}$ Ustawa z 28.08.1997 r. - Prawo o ustroju sądów powszechnych oraz niektórych innych ustaw, Dz.U. z 1997 r. Nr 124, poz. 782 ze zm.

${ }^{24}$ Ustawa z 20.06.1985 r. o prokuraturze, Dz.U. z 1985 r. Nr 31, poz. 138 ze zm.
} 
powszechnego ubezpieczenia społecznego nie ma charakteru podmiotowego, rozumianego w ten sposób, że nie podlegają oni ubezpieczeniu bez względu na rodzaj prowadzonej działalności, a tylko przedmiotowy. Nie podlegają ubezpieczeniu z tytułu wykonywania swej funkcji i w zakresie wypłacanego im z tego tytułu uposażenia ${ }^{25}$. W konsekwencji, sędzia nie jest wyłączony z ubezpieczenia z tytułu działalności zarobkowej objętej systemem ubezpieczeń społecznych wykonywanej poza służbą sędziowską ${ }^{26}$. Gdy sędzia lub prokurator zostanie zatrudniony na podstawie umowy o prace jako nauczyciel akademicki, to jako pracownik będzie obowiązkowo podlegał ubezpieczeniom społecznym. Tak samo będzie, gdy zawrze umowę zlecenia lub będzie miał inny tytuł do ubezpieczeń wymieniony w tym przepisie ${ }^{27}$.

Zgodnie z art. 8 ust. 2 ustawy o systemie ubezpieczeń społecznych, za pracownika uważa się także osobę wykonującą pracę na podstawie umowy agencyjnej, umowy zlecenia lub innej umowy o świadczenie usług, do której zgodnie z Kodeksem cywilnym stosuje się przepisy dotyczące zlecenia albo umowy o dzieło, jeżeli umowę taką zawarła z pracodawcą, z którym pozostaje w stosunku pracy lub jeżeli w ramach takiej umowy wykonuje pracę na rzecz pracodawcy, z którym pozostaje w stosunku pracy. W wystąpieniach kierowanych do resortu pracy, zarówno ubezpieczeni, jak i w ich imieniu związki zawodowe wskazywały, że regulacja ta stanowi pole do nadużyć ze strony części płatników składek, którzy korzystając z konstrukcji przepisu, w przypadku kilku umów zlecenia, ubezpieczają zleceniobiorców z tytułu wykonywania najniżej płatnej umowy (częstokroć kilkudziesięciozłotowej), z pozostałych umów odprowadzając jedynie składkę na ubezpieczenie zdrowotne. $Z$ korespondencji kierowanej do resortu pracy wynikało, że ta praktyka jest stosowana wbrew woli zleceniobiorców, którzy - jako podmiot słabszy na rynku pracy - nie mają realnych możliwości wyboru wyższego ubezpieczenia. To powoduje, że pomimo wielu lat ubezpieczenia, nie mają oni szansy wypracowania sobie chociażby minimalnego świadczenia emerytalnego czy rentowego. Również gdy zachorują lub ulegną wypadkowi - przysługujące im świadczenie z ubezpieczenia wypadkowego (ewentualnie chorobowego) będzie nieadekwatne do utraconych zarobków $^{28}$. Ustawodawca uznał za słuszne wprowadzenie rozwiązań zmierzających do zapewnienia wykonującym ją podmiotom większej ochrony ubezpieczeniowej. Uwzględniając zarówno interes ubezpieczonego, jak i płatnika składek

\footnotetext{
${ }^{25}$ G. Wolak, op. cit., s. 29.

${ }^{26}$ Uzasadnienie uchwały Sądu Najwyższego z 09.11.1999 r., III ZP 16/99, OSNAPiUS 2000/7/283; uzasadnienie uchwały Sądu Najwyższego z 13.02.2001 r., III ZP 38/00, OSNAPiUS 2002/19/468, OSP 2002/10/132 z aprobującą glosą K. Kolasińskiego.

${ }^{27}$ A. Radzisław, Zasady podlegania ubezpieczeniom społecznym, [w:] J. Wantoch-Rekowski (red.), Ustawa o systemie ubezpieczeń społecznych, Komentarz, Lex 2015.

${ }^{28}$ Uzasadnienie do ustawy o systemie ubezpieczeń społecznych, s. 2-3, http://www.sejm.gov.pl/ sejm7.nsf/druk.xsp?nr=2242 (dostęp: 26.04.2016).
} 
oraz aktualną sytuację gospodarczą, prawodawca uznał za celowe zrównanie wykonywania umowy zlecenia z innymi tytułami, których posiadanie powoduje sumowanie podstaw wymiaru składek do kwoty co najmniej minimalnego wynagrodzenia. Art. 9 ustawy systemowej rozstrzyga, które z będących w zbiegu tytułów są tytułami do obowiązkowych ubezpieczeń emerytalnego i rentowych, a które dają jedynie prawo zgłoszenia się do dobrowolnych ubezpieczeń emerytalnego i rentowych bądź nie stanowi tytułu do ubezpieczeńn ${ }^{29}$.

W przypadku zatrudnienia pracownika na podstawie różnych umów tj. umowy o pracę i np. umowy zlecenie u tego samego pracodawcy, powstaje obowiązek po stronie pracodawcy odprowadzenia składek od każdej z tych umów, tak jakby każda $\mathrm{z}$ nich byłą umową o pracę eq $^{30}$ Osoba, która wykonuje pracę na podstawie umowy agencyjnej, umowy zlecenia lub innej umowy o świadczenia usług, albo na podstawie umowy o dzieło, którą zawarła z własnym pracodawcą, lub w ramach której pracownik wykonuje na jego rzecz pracę, jest w zakresie ubezpieczeń społecznych traktowana tak, jak pracownik. Dlatego w takim przypadku nie mamy do czynienia ze zbiegiem dwóch tytułów do ubezpieczeń społecznych ${ }^{31}$.

Jednak bardzo często mamy do czynienia z sytuacją, w której pracownicy wykonują pracę na podstawie jednej z ww. umów cywilnoprawnych, których nie zawarli z własnym pracodawcą, ani nie wykonują ich w ramach pracy na rzecz własnego pracodawcy. Jeżeli jest to umowa agencyjna, umowa zlecenie lub inna umowa o świadczenie usług, wówczas mamy do czynienia z sytuacją, w której ubezpieczony z punktu widzenia przepisów ustawy systemowej jest pracownikiem ${ }^{32}$. Zawsze w takim przypadku tytułem do obowiązkowych ubezpieczeń społecznych jest stosunek pracy, natomiast to, czy takim tytułem będzie również wykonywana przez pracownika umowa cywilnoprawna, uzależnione jest od wysokości podstawy wymiaru składek na ubezpieczenia emerytalne i rentowe $\mathrm{z}$ tytułu stosunku pracy ${ }^{32}$. W przypadku, gdy podstawa jest co najmniej równa kwocie obowiązującego minimalnego wynagrodzenia za pracę, to umowa cywilnoprawna stanowi wyłącznie tytuł do dobrowolnych ubezpieczeń emerytalnego i rentowych ${ }^{33}$. W konsekwencji obowiązek ubezpieczeń społecznych w przypadku pracownika, który równocześnie ma inny tytuł do ubezpieczeń, będzie dotyczył osób zatrudnionych na część etatu, gdy ich wynagrodzenie jest niższe od minimalnego ${ }^{34}$.

\footnotetext{
${ }^{29}$ P. Kostrzewa, [w:] M. Stojek-Siwińska (red.), Ubezpieczenia społeczne 2008, W-wa 2008, s. 96. ${ }^{30}$ K. Kamińska, http://prawopracy.tomczak.pl/blog/2015/04/29/definicja-pracownika-na-gruncieprawa-ubezpieczen-spolecznych (dostęp: 06.04.2016).

${ }^{31}$ P. Kostrzewa, op. cit., s. 96.

${ }^{32}$ Ibidem, s. 97.

${ }^{33}$ A. Radzisław, Komentarz do ustawy o systemie ubezpieczeń społecznych, [w:] J. Wantoch-Rekowski (red.), Ustawa o systemie ubezpieczeń społecznych. Komentarz, Lex 2015.

${ }^{34}$ A. Radzisław, op. cit.
} 
Ustawodawca uzasadniając wprowadzone zmiany wynikające $\mathrm{z}$ art. 8 ust. 2a podał dążenie do objęcia ubezpieczeniem społecznym i zdrowotnym wszystkich zleceniobiorców niezależnie od okresu, na który została zawarta umowa, a także objęcie obowiązkiem opłacania składek na ubezpieczenie przychodów z umów zlecenia i o dzieło zawartych z tym samym pracodawcą. Mając na względzie ochronną funkcję pracownika, jako metoda odwołania udzielonego zwolnienia z obowiązku opłacania składki, była o tyle uzasadniona, że bezpośrednie uchylenie zwolnienia mogłoby dotyczyć wyłącznie umów zleceń, ale nie przeszkodziłoby zawieraniu umów o dzieło, które podlegają obowiązkowi ubezpieczenia społecznego ${ }^{35}$. Ustawodawca, stosując konstrukcję prawną uznania za pracownika, zawartą w powyższym artykule osiągnął kilka efektów:

1) zapobiegł unikaniu opłacania składki od umów o pracę w wyniku ,przerzucenia" części wynagrodzenia do umowy zlecenia,

2) przeszkodził w „uciekaniu” do umów o dzieło,

3) objął obowiązkiem ubezpieczenia wypadkowego osoby wykonujące umowy zlecenia w sytuacji wykonywania zlecenia poza siedzibą zleceniodawcy ${ }^{36}$.

Zgodnie ze stanowiskiem Sądu Najwyższego z 23 maja 2014 r., art. 8 ust. 2a ustawy poprzez stworzenie szerokiego pojęcia pracownika, stworzył tym samym także szeroką definicję pracowniczego tytułu objęcia obowiązkowym ubezpieczeniem społecznym ${ }^{37}$.

Hipotezą normy prawnej wynikającej z art. 8 ust. 2 ustawy systemowej objęte są dwie sytuacje. W pierwszej chodzi o wykonywanie pracy na podstawie jednej z wymienionych umów prawa cywilnego przez osobę, która dodatkową umowę cywilną zawarła ze swoim pracodawcą. Druga sytuacja dotyczy wykonywania pracy na podstawie jednej z wymienionych umów prawa cywilnego przez osobę, która umowę taką zawarła $\mathrm{z}$ osobą trzecią, ale w ramach tej umowy wykonuje pracę na rzecz pracodawcy, z którym pozostaje w stosunku pracy ${ }^{38}$. Przesłanką decydującą o uznaniu takiej osoby za pracownika w rozumieniu ustawy systemowej jest to, że - będąc pracownikiem związanym stosunkiem pracy z określonym pracodawcą - jednocześnie świadczy na jego rzecz pracę $w$ ramach umowy cywilnoprawnej zawartej z inną osobą ${ }^{39}$.

\footnotetext{
${ }^{35}$ I. Jędrasik-Jankowska, Pojęcia i konstrukcje prawne ubezpieczenia społecznego, Warszawa 2016, s. 75-76.

${ }^{36}$ Ibidem, s. 76.

${ }^{37}$ Wyrok Sądu Najwyższego z 23.05.2014, II UK 445/13, Lex nr 1475168, zob. wyrok Sądu Apelacyjnego w Białymstoku z 11.02.2015 r., III AUa 10718/14, niepublikowany; wyrok Sądu Najwyższego z 03.04.2014 r., II UK 399/13, niepublikowany; wyrok Sądu Najwyższego w Katowicach z 13.03.2014 r., III AUa 147/14, niepublikowany; wyrok Sądu Najwyższego z 06.02.2014 r., II UK 279/13, niepublikowany; wyrok Sądu Okręgowego w Białymstoku z 25.11.2013 r., V U 893/13, niepublikowany.

${ }^{38}$ K. Kamińska, http://prawopracy.tomczak.pl/blog/2015/04/29/definicja-pracownika-na-gruncieprawa-ubezpieczen-spolecznych (dostęp: 06.04.2016).

${ }^{39}$ Wyrok Sądu Najwyższego z 23.05.2014, II UK 445/13, Lex nr 1475168.
} 
Jak wskazuje się w judykaturze zwrot działać „na rzecz” należy tutaj rozumieć inaczej niż w języku prawa, w którym to „działanie na czyjąś rzecz” może się odbywać w wyniku istnienia określonej więzi prawnej tj. stosunku prawnego ${ }^{40}$. W kontekście przepisu art. 8 ust. 2a zwrot ten opisuje sytuację w znaczeniu faktycznym ${ }^{41}$, w której należy zastosować konstrukcję uznania za pracownika. W orzecznictwie i literaturze ten układ stosunków prawnych ujmowany jest w postaci trójkąta umów ${ }^{42}$, w której świadczenie usług realizowanych ze stosunku prawnego łączącego zleceniobiorcę z osobą trzecią w rezultacie przynosi korzyść pracodawcy. Zatem pojęcie „wykonywania pracy na rzecz” należy rozumieć jako przysparzanie korzyści pracodawcy ${ }^{43}$. Osoby, o których mowa w art. 8 ust. 2a ustawy systemowej podlegają obowiązkowym ubezpieczeniom społecznym z tytułu stosunku pracy oraz umów cywilnoprawnych, o których mowa we wspomnianym artykule. Przychody z tych źródeł podlegają zsumowaniu i stanowią podstawę wymiaru składek na ubezpieczenie emerytalne, rentowe, wypadkowe i chorobowe ${ }^{44}$. Umowy cywilnoprawne wymienione w art. 8 ust. 2a ustawy o systemie ubezpieczeń społecznych nie stanowią samodzielnych tytułów obowiązkowego podlegania ubezpieczeniom społecznym pracownika. Zgodnie ze stanowiskiem judykatury w takiej sytuacji nie dochodzi również do zbiegu tytułów ubezpieczenia społecznego w rozumieniu art. 9 tejże usta$\mathrm{wy}^{45}$.

Ustawa o systemie ubezpieczeń społecznych w art. 8 ust. 2 kreuje jeden szeroko ujęty pracowniczy tytuł do objęcia ubezpieczeniem społecznym, płatnikiem składek w tym przypadku jest pracodawca, z którym to pracownika łączy stosunek pracy. Pracodawca uprawniony jest do zasięgania informacji od samego pracownika o przychodach pracownika dla realizacji wskazanego celu. Powyższe zasięganie informacji nie może być kwalifikowane jako naruszenie konstytucyjnych gwarancji w zakresie ochrony danych osobowych oraz obrazy dóbr osobistych ${ }^{46}$.

\footnotetext{
${ }^{40}$ Pojęcie pracownika i konsekwencje pracy wykonywanej dla pracodawcy na podstawie umów cywilnoprawnych zawartych $z$ pracodawca oraz z osobami trzecimi $w$ prawie ubezpieczeń społecznych, opracowanie redakcyjne E.S., „Monitor Prawa Pracy” nr 1/2016.

${ }^{41}$ Wyrok SN z 27.11.2014 r., III AUa 476/14, zob.: wyrok SA w Szczecinie z 10.02.2015 r., III AUa 378/14, niepubl.; wyrok SA w Gdańsku z 17.09.2014 r., III AUa 2714/13, niepubl.

${ }^{42}$ A. Kurzych, [w:] M. Szabłowska-Juckiewicz, M. Wałachowska (red.), Umowy cywilnoprawne w ubezpieczeniach społecznych, Lex 2016.

${ }^{43}$ Wyrok SA w Gdańsku z 25.02.2015 r., III AUa 1568/14, niepubl.; wyrok SA w Białymstoku z 21.10.2014 r., III AUa 905/14, niepubl.; wyrok SA w Gdańsku z 27.06.2013, III AU 2027/12.

${ }^{44}$ A. Laskowska-Hulisz, L. Ramlo, [w:] J. Wantoch-Rekowski (red.), Ustawa o systemie ubezpieczeń spotecznych. Komentarz, Warszawa, Lex 2015.

${ }^{45}$ Wyrok SN z 04.06.2014 r., II UK 447/13, niepubl.; wyrok SN z 23.05.2014 r., II UK 445/13, Lex 1475168; wyrok SN z 06.05.2014 r., II UK 442/13, niepubl.

${ }^{46}$ Wyrok SA w Rzeszowie z 25.06.2015 r., III AUa 207/15, niepubl.; wyrok SA w Gdańsku z 12.09.2014 r., III AUa 2619/13, niepubl.
} 
Ustawa systemowa przewiduje wyjątek od ogólnej definicji pracownika zawarty w art. 8 ust. 2. Osoba zatrudniona na podstawie umowy o pracę, pomimo że jest pracownikiem, dla celów ubezpieczeń społecznych będzie traktowana jak osoba współpracująca, jeśli spełnia kryteria określone w art. 8 ust. 11 dla uznania jej za osobę współpracującą, chyba, że jest to osoba zatrudniona w celu przygotowania zawodowego ${ }^{47}$. Ograniczenie ma związek z osobą współpracującą z płatnikiem składek, która jest osobą fizyczną prowadzącą działalność gospodarczą lub jest zleceniodawcą ${ }^{48}$.

Prowadzenie pozarolniczej działalność oraz wykonywanie umów zlecenia lub agencyjnej może się odbywać przy pomocy członków rodziny. Do grona osób współpracujących ustawodawca zaliczył: małżonka, dzieci własne, dzieci drugiego małżonka i dzieci przysposobione, rodziców, macochę i ojczyma oraz osoby przysposabiające. Ustawodawca w art. 8 ust. 11 zawarł katalog zamknięty, w którym wskazał dwie kategorie osób współpracujących.

Pierwsza kategoria, to osoby współpracujące z osobami prowadzącymi pozarolniczą działalność gospodarczą, druga zaś kategoria dotyczy osób współpracujących ze zleceniobiorcami. Dodatkowymi warunkami, jakie muszą być spełnione, aby osoba została uznana za współpracującą, są pozostawanie we wspólnym gospodarstwie domowym oraz współpraca przy prowadzeniu działalności gospodarczej. Ustawodawca nie definiuje pojęć: „pozostawanie we wspólnym gospodarstwie” oraz „współpracy” ponieważ doktryna i orzecznictwo wskazują na kryteria pozwalające stwierdzić, czy dane osoby prowadzą wspólne gospodarstwo domowe czy też współpracują. To czy prowadzi się wspólne gospodarstwo zależy od okoliczności konkretnej sytuacji ${ }^{49}$. W praktyce jednak, ustalenie tej okoliczności dostarcza wielu kłopotów ${ }^{50}$. W orzecznictwie, za kryteria decydujące o wspólnym gospodarstwie domowym przyjmuje się wspólny budżet domowy oraz wspólne koszty prowadzenia jednego gospodarstwa domowego dla osoby prowadzącej działalność gospodarczą i dla osoby współpracującej ${ }^{51}$. Fakt wspólnego zamieszkiwania nie może mieć decydującego znaczenia ${ }^{52}$. W związku z powyższym, nie zawsze wspólne zamieszkiwanie osób, nawet ze sobą spokrewnionych, uznawane będzie za wspólne prowadzenie gospodarstwa domowego. Przykładowo, jeżeli dorosły syn mający własną rodzinę, mieszka $\mathrm{z}$ rodzicami i pracuje w przedsiębiorstwie ojca, to jednak nie pozostaje z rodzicami we wspólnym gospodarstwie domowym. Wynika

\footnotetext{
${ }^{47}$ P. Kostrzewa, [w:] J. Kuźniar, E. Dziubińska-Lechnio (red.), Ubezpieczenia społeczne, Warszawa 2014, s. 27.

${ }^{48}$ A. Laskowska-Hulisz, L. Ramlo, op. cit.

${ }^{49}$ Wyrok Sądu Najwyższego z 02.02.1996 r., II URN, 56/95, OSNP 1996, nr 16, poz. 240.

${ }^{50}$ P. Kostrzewa, Zasady podlegania ubezpieczeniom spolecznym, [w:] M. Stojek-Siwińska (red.), Ubezpieczenia społeczne 2008, Warszawa 2008, s. 74.

${ }^{51}$ Wyrok Sądu Apelacyjnego w Katowicach z 21.12.2011 r., III AUa 724/11.

${ }^{52}$ Wyrok Sądu Najwyższego z 02.02.1996 r., II URN 56/95, OSNP 1996, nr 16, poz. 240.
} 
to z faktu, że osoby te stanowią odrębne rodziny, które charakteryzują odmienne cele $^{53}$. Podobnie nie pozostają we wspólnym gospodarstwie domowym dwie dorosłe siostry razem mieszkające, niezależne finansowo. Praca jednej z nich u drugiej prowadzącej pozarolniczą działalność gospodarczą może się odbywać na podstawie umowy o pracę ${ }^{54}$. W sytuacji, gdy członkowie rodziny nie zamieszkują razem, nie posiadają wspólnego budżetu domowego, to nie można przyjąć, że prowadzą wspólne gospodarstwo. Współpraca przy prowadzeniu działalności gospodarczej polega na wykonywaniu czynności, mających bezpośredni związek z działalnością gospodarczą o charakterze stałym, zorganizownym, które stanowią istotny wkład w działalność przedsiębiorcy. Okazjonalna pomoc przy prowadzeniu działalności nie skutkuje zatem uznaniem członka rodziny za osobę współpracującą.

Porównując sytuację pracownika oraz osoby współpracującej należy zwrócić uwagę na pewne odmienności jakie występują pomiędzy tymi dwoma tytułami ubezpieczenia.

Osoby współpracujące, bez względu na to, czy współpracują z osobą prowadzącą pozarolniczą działalność czy też ze zleceniobiorcą, objęte są obowiązkiem ubezpieczeń społecznych w takim samym zakresie jak osoba, z którą współpracują, tj. osobą prowadzącą pozarolniczą działalność albo zleceniobiorcą. Tym samym dla osób współpracujących obowiązkowe co do zasady, są ubezpieczenia emerytalne, rentowe i wypadkowe, a ubezpieczenie chorobowe jest jedynie dobrowolne ${ }^{55}$. Pracownicy są jedną z tych grup ubezpieczeniowych, której reprezentanci podlegają ubezpieczeniom społecznym w pełnym zakresie, a więc objęci są zarówno obowiązkiem ubezpieczenia emerytalnego i rentowych, jak również obowiązkiem ubezpieczenia chorobowego i wypadkowego.

Osoba współpracująca objęta jest obowiązkiem ubezpieczeń społecznych w okresie od dnia rozpoczęcia współpracy przy prowadzeniu pozarolniczej działalności lub wykonywania umowy agencyjnej, lub umowy zlecenia, do dnia zakończenia tej współpracy, lub ustania którejkolwiek z przesłanek, np. prowadzenia wspólnego gospodarstwa domowego.

Z. Myszka na podstawie analizy orzecznictwa Sądu Najwyższego (wyrok z 20.05.2008, II UK 286/07, Lex 516822) stwierdził, że „stosunek pracy nie mieści się w pojęciu współpracy przy prowadzeniu działalności gospodarczej" ${ }^{56}$.

\footnotetext{
${ }^{53}$ Wyrok Sądu Administracyjnego w Krakowie z 19.02.2009 r., III SA/Kr 864/08; wyrok Sądu Administracyjnego w Lublinie z 27.11.2009 r., II SA/Lu 587/09.

${ }^{54}$ I. Jędrasik-Jankowska, Pojęcie i konstrukcje prawne ubezpieczenia społecznego, t.1, Warszawa 2006, s. 66.

${ }^{55}$ P. Kostrzewa, Zasady podlegania ubezpieczeniom społecznym, [w:] M. Stojek-Siwińska (red.), op. cit., s. 74.

${ }^{56}$ Z. Myszka, Glosa do uchwały Sądu Najwyższego z 28.09.1994, II UZP 27/94, „PiZS” 1996, nr 5, s. 74-82.
} 
Podobne stanowisko zajęła A. Pasternak, która uważa, że pojęcia „współpraca" oraz „stosunek pracy" mają inne zakresy pojęciowe ${ }^{57}$. W języku polskim słowo „współpraca” oznacza wykonywać pracę wspólnie z kimś. W związku z powyższym, pojęcie współpracy przy prowadzeniu działalności gospodarczej ma szersze znaczenie pojęciowe niż stosunek pracy, który zawiera się w nim. W innej uchwale Sąd Najwyższy wyraził pogląd, że „osoba współpracującą” może być tylko taka osoba, z którą nie zawarto żadnej umowy wskazującej na rodzaj świadczonej pracy. W szczególności nie może nią być pracownik, gdyż współpraca jest formą współdziałania $\mathrm{z}$ osobą prowadzącą działalność gospodarczą wolną od jakichkolwiek cech konstytutywnych stosunku pracy. Cechą wyróżniającą stosunek pracy spośród innych stosunków prawnych związanych ze świadczeniem pracy jest podległość pracownika pracodawcy w tej dziedzinie, związana $\mathrm{z}$ obowiązkiem zastosowania się do poleceń dotyczących pracy (art. 22 ust. 1 i 100 ust. 1 Kodeksu pracy). W przypadku współpracy może istnieć podporządkowanie, jednak ma ono inny charakter. Obydwoje z małżonków mają możliwość wpływu na decyzje, wykonują te same zadania i często są na równi.

Dzień powstania i dzień ustania obowiązku ubezpieczeń społecznych pracownika wyznacza art. 13 pkt. 1 ustawy systemowej. Z przepisu tego wynika, że obowiązek ubezpieczeń społecznych po stronie pracownika powstaje w dniu nawiązania stosunku pracy, a wygasa $\mathrm{w}$ dniu ustania stosunku prawnego. Jednak nie zawsze oznacza to, że okres ubezpieczeniowy pracownika jest tożsamy $\mathrm{z}$ okresem pozostawania przez niego w stosunku pracy. W okresie korzystania z urlopów pracowniczych takich jak urlop wychowawczy, urlop macierzyński czy urlop bezpłatny, pracownik formalnie pozostaje w stosunku pracy, jednak dla potrzeb ustawy systemowej nie jest uważany za pracownika ${ }^{58}$.

Podstawę wymiaru składek na ubezpieczenia społeczne osoby współpracującej z osobą prowadzącą pozarolniczą działalność gospodarczą, co do zasady stanowi zadeklarowana przez nią kwota, która nie może być niższa od kwoty $60 \%$ prognozowanego przeciętnego wynagrodzenia w danym roku kalendarzowym. Podstawa wymiaru składek na dobrowolne ubezpieczenie chorobowe osoby współpracującej nie może zaś przekraczać miesięcznie kwoty $250 \%$ przeciętnego miesięcznego wynagrodzenia w poprzednim kwartale.

Za przychody ze stosunku pracy w rozumieniu przepisów podatkowych uważa się wszelkiego rodzaju wypłaty pieniężne oraz wartość pieniężną świadczeń w naturze bądź ich ekwiwalenty, bez względu na źródło finansowania tych wypłat i świadczeń, a w szczególności: wynagrodzenia zasadnicze, wynagro-

\footnotetext{
${ }^{57}$ A. Pasternak, Zróżnicowanie tytulu ubezpieczenia zatrudnionych członków rodziny, Annales Universitatis Maria Curie-Skłodowska, Sectio G, Lublin 2015, s. 177.

${ }^{58}$ P. Kostrzewa, Zasady podlegania ubezpieczeniom społecznym, [w:] M. Stojek-Siwińska (red.), op. cit., s. 34.
} 
dzenia za godziny nadliczbowe, różnego rodzaju dodatki, nagrody, ekwiwalenty za niewykorzystany urlop ${ }^{59}$.

Jednak nie wszystkie świadczenia pieniężne lub niepieniężne, które są przychodami ze stosunku pracy w świetle przepisów podatkowych, stanowią podstawę wymiaru składek na ubezpieczenie społeczne pracownika. Podstawy wymiaru składek na ubezpieczenia społeczne nie stanowią bowiem:

1) wynagrodzenia za czas niezdolności do pracy wskutek choroby lub odosobnienia w związku z chorobą zakaźną, które regulują przepisy Kodeksu pracy;

2) przychody ze stosunku pracy, które zostały enumeratywnie wyliczone w art. 2 ust. 1 rozporządzenia Ministra Pracy i Polityki Społecznej z dnia 18 grudnia $1998 \mathrm{r}$. w sprawie szczegółowych zasad ustalania podstawy wymiaru składek na ubezpieczenie emerytalne i rentowe ${ }^{60}$. Artykuł ten stanowi o:

a) nagrodach jubileuszowych (gratyfikacjach), które według zasad określających warunki ich przyznawania przysługują pracownikowi nie częściej niż co 5 lat,

b) nagrodach Ministra Gospodarki za szczególne osiągnięcia w eksporcie,

c) należnościach obliczanych od wielkości efektów uzyskanych przez zastosowanie pracowniczego projektu wynalazczego i za dokumentację dostarczoną bezumownie przez twórcę projektu, przydatną do stosowania projektu oraz nagrodach za wynalazczość, a także nagrodach za prace badawcze i wdrożeniowe,

d) odprawach pieniężnych przysługujących w związku z przejściem na emeryturę lub rentę,

e) odprawach, odszkodowaniach i rekompensatach wypłaconych pracownikowi z tytułu wygaśnięcia lub rozwiązania stosunku pracy,

f) odszkodowaniach wypłaconych byłym pracownikom po rozwiązaniu stosunku pracy, na podstawie umowy o zakazie konkurencji, o której mowa $\mathrm{w}$ art. $101^{2}$ Kodeksu pracy,

Definicja legalna „domownika” w ustawie z 20 grudnia 1990 r. o ubezpieczeniu społecznym rolników ${ }^{61}$ określa osobę, która spełnia łącznie pięć warunków:

- jest osobą bliską rolnikowi,

- pozostaje we wspólnym gospodarstwie domowym z rolnikiem lub zamieszkuje na terenie jego gospodarstwa rolnego albo w bliskim sąsiedztwie,

- ukończyła 16 lat,

\footnotetext{
${ }^{59}$ Ibidem, s. 35.

${ }^{60}$ Rozporządzenie Ministra Pracy i Polityki Społecznej z dnia 18.12.1998 r. w sprawie szczegółowych zasad ustalania podstawy wymiaru składek na ubezpieczenie emerytalne i rentowe, Dz.U. z 1998 r. Nr 161, poz. 1106 ze. zm.

${ }^{61}$ Ustawa z 20.12.1980 r. o ubezpieczeniu społecznym rolników, Dz.U. z 1998 r. Nr 7, poz. 25 ze. zm.
} 
- stale pracuje w tym gospodarstwie rolnym,

- nie jest związana z rolnikiem stosunkiem pracy.

Pojęcie domownika na gruncie ustawy o ubezpieczeniu społecznym rolników zawarte w art. 6 pkt 2 odbiega od tradycyjnego ujęcia tego terminu i jest o wiele szersze niż dotyczące osób współpracujących w niepracowniczych systemach ubezpieczeń społecznych ${ }^{62}$. Przede wszystkim krąg domowników wykracza poza osoby z rodziny oraz nie dotyczy tylko osób prowadzących wspólne gospodarstwo domowe, ale również mieszkające $\mathrm{w}$ gospodarstwie lub w jego bliskim sąsiedztwie.

\section{Podsumowanie}

Dokonane rozważania prowadzą do wniosku, że pojęcie pracownika w rozumieniu ustawy systemowej jest szersze od pojęcia zdefiniowanego w prawie pracy. Zakres podmiotowy ubezpieczenia społecznego z biegiem lat słusznie ulegał rozszerzeniu. Początkowo swoim zasięgiem obejmował tylko osoby pozostające w stosunku pracy. Poszerzenia zakresu podmiotowego dokonywano przez uznanie danej grupy za pracowników albo z uwagi na fakt, że płatnicy (pracodawcy) próbowali unikać opłacania składki i uciekali do zatrudnienia cywilnoprawnego. W wyniku zachodzących zmian ubezpieczenia społeczne stawały się coraz bardziej powszechne, zaś wejście w życie ustawy systemowej spowodowało ujednolicenie systemu prawnego w tym zakresie. Art. 1 ustawy systemowej stanowi, że ubezpieczenie społeczne obejmuje ubezpieczenie od następujących ryzyk: emerytalnego, rentowego, chorobowego i wypadkowego, zaś podstawą wyodrębnienia katalogu podmiotów podlegających obowiązkowi ubezpieczenia jest tytuł ubezpieczenia czyli kryterium źródeł dochodu.

\section{Bibliografia}

\section{Literatura}

Baran K. W. (red.), Kodeks pracy. Komentarz, 2014.

Florek L. (red.), Kodeks pracy. Seria Komentarzy, Lex 2011.

Gudowska B., Ustawa o systemie ubezpieczeń społecznych. Komentarz, [w:] B. Gudowska, J. Strusińska-Żukowska (red.), Ustawa o systemie ubezpieczeń społecznych. Komentarz, Warszawa 2011.

Jędrasik-Jankowska I., Pojęcia i konstrukcje prawne ubezpieczenia społecznego, Warszawa 2016. Jędrasik-Jankowska I., Ubezpieczenie społeczne, Tom 1, Część ogólna, Warszawa 2003.

Korus P., [w:] A. Sobczyk (red.), Kodeks pracy. Komentarz, Legalis 2015.

\footnotetext{
${ }^{62}$ A. Rzetecka-Gil, Komentarz do ustawy z dnia 20 lipca 1990 r., o wliczaniu okresów pracy w indywidualnym gospodarstwie rolnym do pracowniczego stażu pracy, Lex 2008.
} 
Kostrzewa P., [w:] J. Kuźniar, E. Dziubińska-Lechnio (red.), Ubezpieczenia społeczne, Warszawa 2014.

Kostrzewa P., [w:] M. Stojek-Siwińska (red.), Ubezpieczenia społeczne 2008, Warszawa 2008.

Kurzych A., [w:] M. Szabłowska-Juckiewicz, M. Wałachowska (red.), Umowy cywilnoprawne w ubezpieczeniach spolecznych, Lex 2016.

Laskowska-Hulisz A., Ramlo L., [w:] J. Wantoch-Rekowski (red.), Ustawa o systemie ubezpieczeń społecznych. Komentarz, Lex 2015.

Myszka Z., Glosa do uchwały Sądu Najwyższego z 28.09.1994, II UZP 27/94, „PiZS” 1996, nr 5.

Pasternak A., Zróżnicowanie tytulu ubezpieczenia zatrudnionych członków rodziny, Annales Universitatis, Maria Curie-Skłodowska, Sectio G, Lublin 2015.

Radzisław A., Zasady podlegania ubezpieczeniom społecznym, [w:] J. Wantoch-Rekowski (red.), Ustawa o systemie ubezpieczeń społecznych. Komentarz, Warszawa 2015.

Rzetecka-Gil A., Komentarz do ustawy z dnia 20 lipca 1990 r., o wliczaniu okresów pracy w indywidualnym gospodarstwie rolnym do pracowniczego stażu pracy, Lex 2008.

Stanowska O., Zatrudnienie skazanych pozbawionych wolności na podstawie skierowania do pracy, „RPiA”, 2014.

Wolak G., Podleganie przez sędziów ubezpieczeniu społecznemu z tytułu zawarcia umowy zlecenia, ,PIZS” 7/2014.

\section{Akty prawne}

Rozporządzenia Ministra Pracy i Polityki Społecznej z dnia 18.12.1998 r. w sprawie szczegółowych zasad ustalania podstawy wymiaru składek na ubezpieczenie emerytalne i rentowe, Dz.U. z 1998 r., Nr 161, poz. 1106 ze zm.

Rozporządzenie Rady Ministrów z 31.12.1975 r. w sprawie uprawnień pracowniczych osób wykonujących pracę nakładczą, Dz.U. z 1976 r. Nr 3, poz. 19 ze zm.

Ustawa z 06.06.1997 r. Kodeks karny wykonawczy, Dz.U. z 1997 r. Nr 90, poz. 557 ze zm.

Ustawa z 09.05.1996 r. o wykonywaniu mandatu posła i senatora, Dz.U. z 2011 r. Nr 7, poz. 29 ze zm.

Ustawa z 13.10.1998 r. o systemie ubezpieczeń społecznych, Dz.U. z 1998 r. Nr 137, poz. 887 ze zm.

Ustawa z 02.07.2004 r. o swobodzie działalności gospodarczej, Dz.U. z 2004 r. Nr 173, poz. 1807 ze zm.

Ustawa z 20.06.1985 r. o prokuraturze, Dz.U. z 1985 r. Nr 31, poz. 138 ze zm.

Ustawa z 20.12.1980 r. o ubezpieczeniu społecznym rolników, Dz.U. z 1998 r. Nr 7, poz. 25 ze. $\mathrm{zm}$.

Ustawa z 23.04.1964 r. - Kodeks cywilny, Dz.U. z 1964 r. Nr 16, poz. 93 ze zm.

Ustawa z 26.06.1974 r. - Kodeks pracy, Dz.U. z 1998 r. Nr 21, poz. 94 ze. zm.

Ustawa z 28.08.1997 r. - Prawo o ustroju sądów powszechnych oraz niektórych innych ustaw, Dz.U. z 1997 r. Nr 124, poz. 782 ze zm.

\section{Wyroki sądów}

Uzasadnienie uchwały Sądu Najwyższego z 09 listopada 1999 r., III ZP 16/99, OSNAPiUS 2000/7/283.

Uzasadnienie uchwały Sądu Najwyższego z 13 lutego 2001 r., III ZP 38/00, OSNAPiUS 2002/19/468, OSP 2002/10/132 z aprobująca glosą K. Kolasińskiego.

Wyrok Sądu Administracyjnego w Krakowie z 19 lutego 2009 r., III SA/Kr 864/08, Lex nr 541470. Wyrok Sądu Administracyjnego w Lublinie z 27 listopada 2009 r., II SA/Lu 587/09, Lex nr 589183. Wyrok Sądu Apelacyjnego w Białymstoku z 03 września 2014 r., III AUa 1965/13, niepublikowany. 
Wyrok Sądu Apelacyjnego w Białymstoku z 11 lutego 2015 r., III AUa 10718/14, niepublikowany. Wyrok Sądu Apelacyjnego w Białymstoku z 21 października 2014 r., III AUa 905/14, niepublikowany.

Wyrok Sądu Apelacyjnego w Gdańsku z 12 września 2014 r., III AUa 2619/13, niepublikowany. Wyrok Sądu Apelacyjnego w Gdańsku z 17 września 2014 r., III AUa 2714/13, niepublikowany. Wyrok Sądu Apelacyjnego w Gdańsku z 25 lutego 2015 r., III AUa 1568/14, niepublikowany. Wyrok Sądu Apelacyjnego w Gdańsku z 27 czerwca 2013, III AU 2027/12, niepublikowany. Wyrok Sądu Apelacyjnego w Katowicach z 21 grudnia 2011 r., III AUa 724/11, Biul.SAKa 2012/3/30-31.

Wyrok Sądu Apelacyjnego w Rzeszowie z 25 czerwca 2015 r., III AUa 207/15, niepublikowany. Wyrok Sądu Apelacyjnego w Szczecinie z 10 lutego 2015 r., III AUa 378/14, niepublikowany.

Wyrok Sądu Najwyższego w Katowicach z 13 marca 2014 r., III AUa 147/14, niepublikowany.

Wyrok Sądu Najwyższego z 02 lutego 1996 r., II URN, 56/95, OSNP 1996, nr 16, poz. 240.

Wyrok Sądu Najwyższego z 03 kwietnia 2014 r., II UK 399/13, niepublikowany.

Wyrok Sądu Najwyższego z 06 lutego 2014 r., II UK 279/13, niepublikowany.

Wyrok Sądu Najwyższego z 23 maja 2014, II UK 445/13, Lex nr 1475168.

Wyrok Sądu Najwyższego z 27 listopada 2014 r., III AUa 476/14, niepublikowany.

Wyrok Sądu Okręgowego w Białymstoku z 25 listopada 2013 r., V U 893/13, niepublikowany.

\section{Źródla internetowe}

Kamińska K., Definicja pracownika na gruncie prawa ubezpieczeń społecznych, [w:] http:// prawopracy.tomczak.pl/blog (dostęp: 06.04.2016).

Pojęcie pracownika i konsekwencje pracy wykonywanej dla pracodawcy na podstawie umów cywilnoprawnych zawartych $z$ pracodawca oraz z osobami trzecimi w prawie ubezpieczeń spolecznych, opracowanie redakcyjne E.S., „Monitor Prawa Pracy” 1/2016, http://czasopisma.beck.pl/monitor-prawa-pracy/aktualnosc (dostęp: 24.03.2016).

Uzasadnienie do ustawy o systemie ubezpieczeń społecznych, http://www.sejm.gov.pl/sejm7.nsf/ druk.xsp?nr=2242 (dostęp: 26.04.2016). 